\title{
Research on Performance Evaluation System of College Entrepreneurship Education Level Based on CIPP Model*
}

\author{
Xiaoli Shi ${ }^{1}$ \\ Xi'an International University
}

\begin{abstract}
As a brand-new educational concept and education mode, entrepreneurship education has been widely carried out in colleges and universities across the country. A systematic study on the evaluation of college entrepreneurship education is conducive to ensuring the sustainable and stable development of college entrepreneurship education. This paper first analyzes the current status of the development of entrepreneurship education in universities in China. Second, it establishes a CIPP-based evaluation indicator system for university entrepreneurship education capabilities, which includes four main indicators: environmental basis, resource allocation, process action, and result performance, and uses factor analysis to comprehensively evaluate various indicators. Finally, by taking four universities in our country as examples, the indicator weights of university entrepreneurship education ability evaluation are calculated, and then the comprehensive evaluation results of entrepreneurship education level in the four universities are calculated.
\end{abstract}

\section{Keywords}

Entrepreneurship Education • CIPP Model • Factor Analysis Method • Performance Evaluation

\footnotetext{
* Fund for innovative research team of Xi' an International University (grant no. XAIU-KT201805-1)

${ }^{1}$ Correspondence to: Xi'an International University, Yudou Road 18, Yanta District, Xi'an 710077, China. Email: aidp654@126.com
} 
At present, as a brand-new educational concept and education mode, the entrepreneurship education has been widely carried out in colleges and universities nationwide (Fan et al. 2015). How to evaluate and enhance entrepreneurship education in colleges and universities has gradually become the focus and difficulty of education theoretical research. The reasonable evaluation of college entrepreneurship education level is a relatively complicated systematic project. So far, our country has not yet established a relatively complete evaluation system for entrepreneurship education in universities. There is even less research on how to upgrade entrepreneurship education in colleges and universities (Mosqueda et al., 2009). A systematic study of the evaluation of entrepreneurship education in colleges and universities has a very important practical significance and far-reaching impact on ensuring the sustainability, stability and healthy development of college entrepreneurship education (Jablonsky, 2016).

For college entrepreneurship education, a large number of scholars at home and abroad have conducted very systematic and comprehensive research, and also formed a series of research results. The United States is the first country to carry out entrepreneurship education in colleges and universities. It conducts in-depth research and discussion on curriculum setting, teaching methods, and education modes of entrepreneurship education (Liu Chen Bose Hu \& Bruton, 2013); some foreign scholars have studied the evaluation indicator system of college entrepreneurship education (Prathap \& Ratnavelu, 2015); domestic research mainly focuses on the quality evaluation of entrepreneurship education in colleges and universities and existing major problems (Prescott Norcini Mckinlay \& Rennie, 2002). The existing literature mostly stays at the theoretical level. This paper is based on the CIPP model and uses factor analysis to establish an all-round, multi-angle performance evaluation indicator system of entrepreneurship education in colleges and universities, so as to conduct empirical research, and it's of important practical significance.

\section{Introduction of basic theories}

\section{CIPP model}

The CIPP model was first proposed by the American scholar Stufflebeam on the basis of reflection on Tyler's behavioral goal model in 1967 (Behzad Parasto \& Arash 2013). The CIPP model mainly includes four evaluation elements, respectively are: background, input, process, and results. The CIPP model has a strong systemic nature and can provide information for different aspects of decision making. Therefore, the CIPP model is also called a decision-oriented model (Singh, 2004). The CIPP model considers that the purpose of evaluation is not to prove, but to improve (Neyazi Arab Farzianpour \& Mahmoudi, 2016).

\section{Factor analysis}

Factor analysis was first proposed by the famous British psychologist C.E. Spearman in 1904. It is a statistical technique that studies the extraction of commonalities from variable groups (Apley \& Shi, 2001). Factor analysis can be used to find representative factors among a large number of variables and classify variables of the same nature into one factor (Lorber, 1985). It determines the weight of each comprehensive 
factor by the variance contribution rate, which avoids artificial subjective factors and makes the results more reasonable and objective (Trevisan Garcia Schuchardt \& Poppi, 2008).

Assuming that the total sample size is $\mathrm{N}$, each sample has $\mathrm{k}$ original evaluation indicators, which are $\mathrm{X}_{1}$, $\mathrm{X}_{2} \ldots, \mathrm{X}_{\mathrm{k}}$. The $\mathrm{j}$-th indicator of the $\mathrm{i}$-th sample is expressed as $\mathrm{X}_{\mathrm{ij}}=(\mathrm{i}=1,2 \ldots, \mathrm{N} ; \mathrm{j}=1,2 \ldots, \mathrm{K})$, and the evaluation indicator is processed as follows:

Standardized the data. In general, many selected indicators are not comparable, and the indicators need to be standardized in order to perform comparisons (Hopke, 1988). Using dimensionless method to process the raw data can both ensure the consistency of directions and eliminate the influence of dimensions (Stommel Wang Given \& Given, 1992). At present, the Z-score method is commonly used in the world and the conversion formula is:

$$
X_{i j}^{\prime}=X_{i j}-\frac{\overline{X_{J}}}{S_{j}}
$$

Where:

$$
\begin{aligned}
& \bar{X}_{J}=\sum_{i=1}^{n} \frac{x_{i j}}{n} \\
& S_{j}^{2}=\sum_{i=1}^{n} \frac{\left(X_{i j}-\overline{X_{J}}\right)^{2}}{n-1}
\end{aligned}
$$

After the data is standardized, it needs to satisfy:

$$
\mathrm{E}\left(X_{i j}^{\prime}\right)=0, \operatorname{Var}\left(X_{i j}^{\prime}\right)=1
$$

Calculate the eigenvalues and eigenvectors of the correlation coefficient matrix $R$. By the characteristic equation $|\mathrm{R}-\lambda \mathrm{E}|=0$, we can get the characteristic value $\lambda_{\mathrm{m}}(\mathrm{m}=1,2 \ldots, \mathrm{k} ; \mathrm{m}<\mathrm{k})$. Then by the equation set $(\mathrm{R}-\lambda \mathrm{E}) F_{m}=0$, we can get corresponding eigenvectors $\mathrm{F}_{\mathrm{m}}$ of the eigenvalues $\lambda_{\mathrm{m}} . \mathrm{F}_{\mathrm{m}}$ is a linear combination of $\mathrm{X}_{1}, \mathrm{X}_{2} \ldots, \mathrm{X}_{\mathrm{k}}$ and represents factors that play a dominant role in comprehensive performance evaluation (Birnbaum Benfey \& Shasha 2001).

Rotate the factor load matrix. Rotation of the initial factor load matrix usually uses the Varimax method to redefine the common factors by several indicators with larger weights in the linear combination, thereby achieving effective simplification (Miyazaki, et al. 1993).

Establish a comprehensive evaluation model to calculate factor scores. Express the indicator variable as a linear combination of common factors:

$$
X_{i}=a_{i 1} F_{1}+a_{i 2} F_{2}+\cdots+a_{i m} F_{m}(\mathrm{i}=1,2, \cdots, \mathrm{m}, \mathrm{m}<\mathrm{k})
$$

In general, the common factor can be expressed as a linear combination of variables, that is:

$$
F_{j}=\beta_{j 1} X_{1}+\beta_{j 2} X_{2}+\cdots+\beta_{j m} X_{m}(\mathrm{j}=1,2, \cdots, \mathrm{m}, \mathrm{m}<\mathrm{k})
$$


$\beta_{\mathrm{jm}}$ is the factor score of the common factor $F_{j}$ on the indicator variable $X_{n}$. The weighted sum is calculated with the contribution of each common factor as the weight, and finally the comprehensive factor score is obtained:

$$
\mathrm{F}=\sum_{i=1}^{m} \alpha_{i} F_{i}
$$

Where:

$$
\alpha_{i}=\frac{\lambda_{i}}{\sum_{i=1}^{m} \lambda_{i}}
$$

$\lambda_{i}$ is the variance contribution rate, $\frac{\lambda_{i}}{\sum_{i=1}^{m} \lambda_{i}}$ is the cumulative variance contribution rate.

\section{Factor analysis of the performance evaluation of college entrepreneurship education based on CIPP}

Analysis of the status of entrepreneurship education in Chinese universities

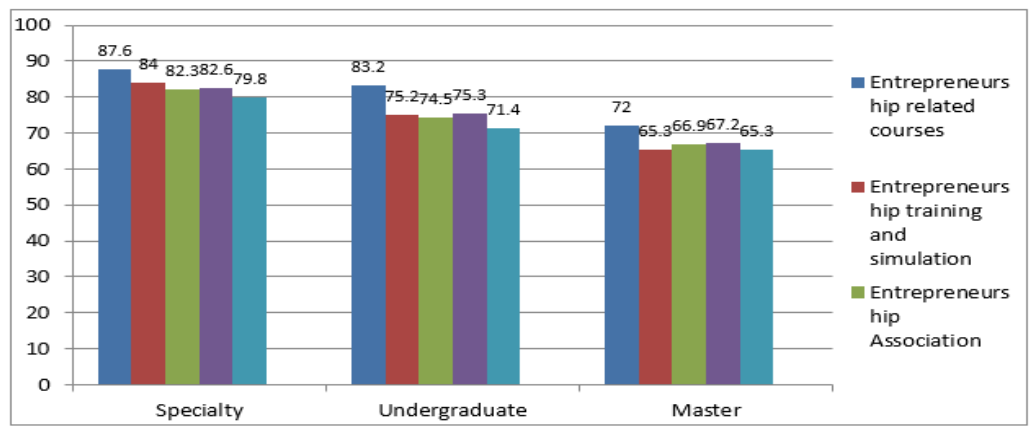

Figure 1. Participation in entrepreneurship education activities

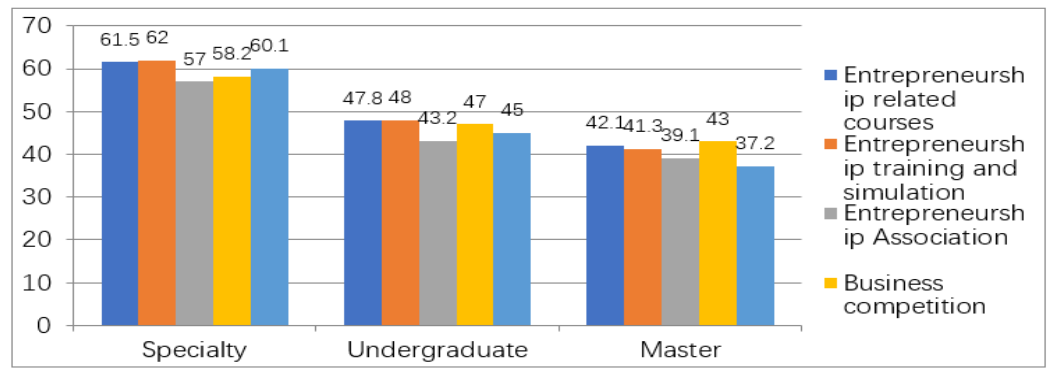

Figure 2. The satisfaction of entrepreneurship education activities

Entrepreneurship education in Chinese universities started in the late 1990s. In April 2002, the pilot work on entrepreneurship education started. At present, many colleges and universities in China have already carried out entrepreneurship education through various means. Students have a relatively high degree of participation, 
as shown in Figure 1. However, overall student satisfaction is not high, as shown in Figure 2. This shows that colleges and universities still need to increase their efforts to promote the sustainable development of college entrepreneurship education.

\section{Establishment of evaluation indicator system for college entrepreneurship education}

According to the research results of domestic and foreign experts, and according to the relevant theories of the CIPP model, this paper establishes an evaluation indicator system for college entrepreneurship education based on the CIPP model. The system mainly includes four major indicators, as shown in Figure 3.

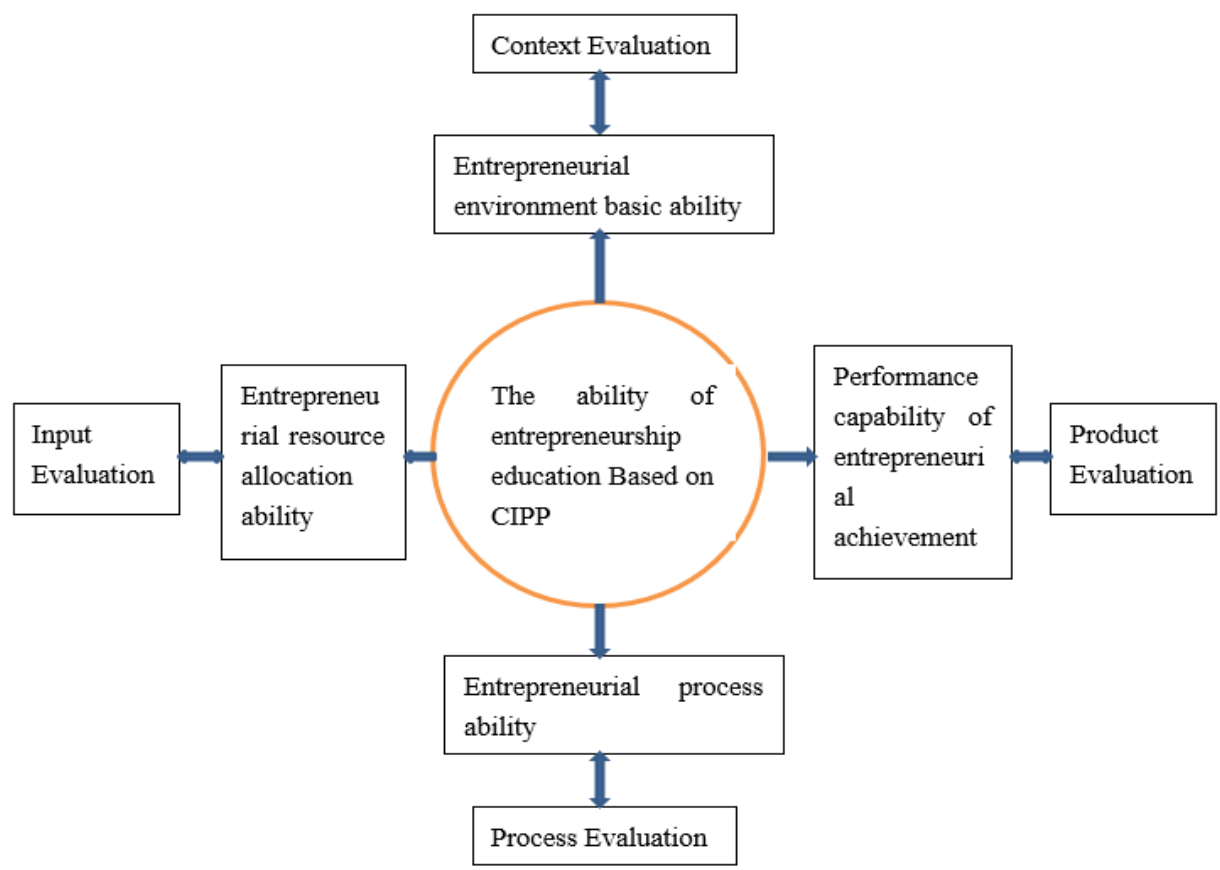

Figure 3. Evaluation model of entrepreneurship education level in Colleges and Universities

The evaluation indicator system of college entrepreneurship education level mainly includes four main indicators: environment basic ability, resource allocation ability, process action ability and result performance ability. Each primary indicator includes several secondary indicators and tertiary indicators. See Table 1 for details.

\section{Factor analysis of performance evaluation}

This paper mainly uses software SPSS 18.0 for factor analysis, and evaluates the level of entrepreneurship education in four universities in China, which are Renmin University of China, Tsinghua University, Wuhan University, and Heilongjiang University. 
Table 1

An Indicator System for Evaluating the Level of Entrepreneurship Education in Colleges and Universities

\begin{tabular}{|c|c|c|}
\hline Primary indicators & Secondary indicators & Tertiary indicators \\
\hline \multirow{5}{*}{$\begin{array}{l}\text { Entrepreneurial } \\
\text { environment basic ability }\end{array}$} & $\begin{array}{l}\text { Regional } \\
\text { environment(A1) }\end{array}$ & $\begin{array}{l}\text { The degree of entrepreneurial activity in the cities of colleges } \\
\text { and Universities(B1) }\end{array}$ \\
\hline & \multirow[t]{2}{*}{ Knowledge base(A2) } & $\begin{array}{l}\text { The number of papers published in CNKI entrepreneurship } \\
\text { education(B2) }\end{array}$ \\
\hline & & CNKI entrepreneurship education paper citation(B3) \\
\hline & \multirow{2}{*}{ Technical basis(A3) } & The amount of authorization of the invention patent(B4) \\
\hline & & Number of contracts signed by technology transfer(B5) \\
\hline \multirow{6}{*}{$\begin{array}{l}\text { Entrepreneurial resource } \\
\text { allocation ability }\end{array}$} & \multirow{4}{*}{ Teacher input(A4) } & $\begin{array}{l}\text { The number of teaching teachers in Entrepreneurship } \\
\text { Education(B6) }\end{array}$ \\
\hline & & $\begin{array}{l}\text { Proportion of Senior Professional Title Teachers in } \\
\text { Entrepreneurship Education(B7) }\end{array}$ \\
\hline & & $\begin{array}{l}\text { Proportion of teachers with high degree of education and } \\
\text { Entrepreneurship Education(B8) }\end{array}$ \\
\hline & & Financial allocation of national Entrepreneurship Program(B9) \\
\hline & Funds input(A5) & $\begin{array}{l}\text { The number of University appropriations for national } \\
\text { Entrepreneurship Program(B10) }\end{array}$ \\
\hline & $\begin{array}{l}\text { Organizational } \\
\text { guarantee(A6) }\end{array}$ & The number of business consulting service centers(B11) \\
\hline \multirow{3}{*}{$\begin{array}{l}\text { Entrepreneurial process } \\
\text { action ability }\end{array}$} & $\begin{array}{l}\text { Entrepreneurship } \\
\text { course(A7) }\end{array}$ & $\begin{array}{l}\text { The number of entrepreneurship education courses(B12) } \\
\text { Entrepreneurship education lecture / Sharon's diversity(B13) }\end{array}$ \\
\hline & $\begin{array}{l}\text { Entrepreneurship } \\
\text { Project(A8) }\end{array}$ & $\begin{array}{l}\text { The national business plan project number(B14) } \\
\text { Student participation in national Entrepreneurship } \\
\text { Program(B15) }\end{array}$ \\
\hline & Practice platform(A9) & The number of Science Park, Pioneer Park, incubator (B16) \\
\hline \multirow{4}{*}{$\begin{array}{l}\text { Entrepreneurial result } \\
\text { performance ability }\end{array}$} & $\begin{array}{l}\text { Literacy } \\
\text { promotion(A10) }\end{array}$ & $\begin{array}{l}\text { Award-winning scores in the national competition program of } \\
\text { College Students' Entrepreneurship Program(B17) } \\
\text { The improvement of the psychological characteristics of } \\
\text { College Students' entrepreneurial personality(B18) }\end{array}$ \\
\hline & \multirow{2}{*}{$\begin{array}{l}\text { Entrepreneurial } \\
\text { effect(A11) }\end{array}$} & $\begin{array}{l}\text { The number of incubating enterprises in the University Science } \\
\text { Park(B19) }\end{array}$ \\
\hline & & $\begin{array}{l}\text { The number of accumulative graduation enterprises in } \\
\text { University Science and Technology Park(B20) }\end{array}$ \\
\hline & Social results(A12) & $\begin{array}{l}\text { The ratio of entrepreneurial rate and employment rate(B21) } \\
\text { Number of outstanding entrepreneurs(B22) }\end{array}$ \\
\hline
\end{tabular}

\section{Entrepreneurial environment basic ability evaluation}

Table 2

Test Results of KMO and Bartlett for Entrepreneurial Environment Basic Ability Evaluation

\begin{tabular}{llc}
\hline KMO Value & & 0.54 \\
\hline & Approximate chi square & 32.794 \\
Bartlett sphericity test & Freedom & 5 \\
& Saliency & 0.001 \\
\hline
\end{tabular}

Table 2 shows that the KMO statistic for each indicator of the basic ability of the entrepreneurial environment is 0.54 , and the $\mathrm{P}$ value is 0.001 . Therefore, it is suitable for factor analysis. The results of the eigenvalue and variance contribution of each indicator are shown in Table 3.

Table 3

Eigenvalue and Variance Contribution Rate of Entrepreneurial Environment Basic Ability Evaluation Indicators

\begin{tabular}{cccc}
\hline Principal component & Characteristic value & Contribution rate & Cumulative contribution value \\
\hline 1 & 2.375 & $45.382 \%$ & $45.382 \%$ \\
2 & 1.984 & $36.729 \%$ & $82.111 \%$ \\
3 & 1.153 & $12.821 \%$ & $94.932 \%$ \\
4 & 0.248 & $4.152 \%$ & $99.084 \%$ \\
5 & 0.067 & $0.916 \%$ & $100.000 \%$ \\
\hline
\end{tabular}


According to Table 3, the cumulative contribution rate of the first three factors is $94.932 \%$, far exceeding $85 \%$, indicating that the first three factors can fully explain the indicator of entrepreneurial environment basic ability. See Table 4 for the rotation load matrix.

Table 4

Rotation Load Matrix of Factor Analysis for Entrepreneurial Environment Basic Ability Evaluation Indicators

\begin{tabular}{lccc}
\hline \multirow{2}{*}{ Index } & \multicolumn{3}{c}{ Factor } \\
\cline { 2 - 4 } & $\mathrm{F}_{1}$ & $\mathrm{~F}_{2}$ & $\mathrm{~F}_{3}$ \\
\hline B1 & -0.005 & 0.327 & 0.904 \\
B2 & 0.987 & -0.046 & -0.004 \\
B3 & 0.985 & -0.017 & 0.003 \\
B4 & 0.059 & 0.939 & 0.296 \\
B5 & -0.123 & 0.934 & 0.172 \\
\hline
\end{tabular}

As can be seen from Table 4, the two indicators included in the knowledge base contribute the most to the basic capabilities of the college's entrepreneurial environment, followed by the technical infrastructure and the regional environment. The score coefficient matrix for the three factors is shown in Table 4.

Table 5

Component Score Coefficient Matrix of Entrepreneurial Environment Basic Ability Evaluation

\begin{tabular}{lccc}
\hline Index & $\mathrm{F}_{1}$ & $\mathrm{~F}_{2}$ & $\mathrm{~F}_{3}$ \\
\hline B1 & -0.028 & -0.314 & 1.294 \\
B2 & 0.492 & 0.023 & -0.014 \\
B3 & 0.527 & 0.029 & -0.018 \\
B4 & 0.071 & 0.547 & -0.121 \\
B5 & -0.026 & 0.651 & -0.317 \\
\hline
\end{tabular}

According to Table 5, it can be concluded that the linear combinations between the evaluation indicators are:

$$
\begin{aligned}
& F_{1}=-0.028 \mathrm{~B}_{1}+0.492 \mathrm{~B}_{2}+0.527 \mathrm{~B}_{3}+0.071 \mathrm{~B}_{4}-0.026 \mathrm{~B}_{5} \\
& F_{2}=-0.314 \mathrm{~B}_{1}+0.023 \mathrm{~B}_{2}+0.029 \mathrm{~B}_{3}+0.547 \mathrm{~B}_{4}+0.651 \mathrm{~B}_{5} \\
& F_{3}=1.294 \mathrm{~B}_{1}-0.014 \mathrm{~B}_{2}-0.018 \mathrm{~B}_{3}-0.121 \mathrm{~B}_{4}-0.317 \mathrm{~B}_{5}
\end{aligned}
$$

According to the factor score coefficient matrix, a comprehensive scoring model can be established:

$$
\mathrm{F}=\sum_{i=1}^{m} \alpha_{i} F_{i}=0.47328 \times F_{1}+0.39382 \times F_{2}+0.11396 \times F_{3}
$$

\section{Evaluation of entrepreneurial resources allocation ability}

Table 6

Test results of KMO and Bartlett for entrepreneurial resource allocation ability evaluation

\begin{tabular}{llc}
\hline KMO Value & & 0.561 \\
\hline & Approximate chi square & 25.195 \\
Bartlett sphericity test & Freedom & 10 \\
& Saliency & 0.039 \\
\hline
\end{tabular}

Table 6 shows that the KMO statistic for each indicator of the entrepreneurial resource allocation ability is 0.561 , and the $\mathrm{P}$ value is 0.051 . It is suitable for factor analysis. Table 7 shows the eigenvalues and variance contribution results of each indicator. 
Table 7

Eigenvalue and variance contribution rate of entrepreneurial resource allocation ability evaluation indicators

\begin{tabular}{cccc}
\hline Principal component & Characteristic value & Contribution rate & Cumulative contribution value \\
\hline 1 & 2.398 & $40.538 \%$ & $40.538 \%$ \\
2 & 1.963 & $31.296 \%$ & $71.834 \%$ \\
3 & 1.054 & $16.215 \%$ & $88.049 \%$ \\
4 & 0.315 & $6.723 \%$ & $94.772 \%$ \\
5 & 0.162 & $4.683 \%$ & $99.455 \%$ \\
6 & 0.027 & 0.545 & $100.000 \%$ \\
\hline
\end{tabular}

From Table 7, we can see that the cumulative contribution rate of the first three factors is $88.048 \%$, which is higher than $85 \%$. This shows that the first three factors can fully explain the indicator of entrepreneurial resource allocation ability. See Table 8 for the rotation load matrix.

Table 8

Rotation Load Matrix of Entrepreneurial Resource Allocation Ability Evaluation Indicators

\begin{tabular}{lccc}
\hline \multirow{2}{*}{ Index } & \multicolumn{3}{c}{ Factor } \\
\cline { 2 - 4 } & $\mathrm{F}_{1}$ & $\mathrm{~F}_{2}$ & $\mathrm{~F}_{3}$ \\
\hline B6 & -0.579 & 0.792 & -0.391 \\
B7 & 0.035 & 0.896 & 0.247 \\
B8 & 0.114 & 0.924 & -0.028 \\
B9 & 0.941 & 0.147 & -0.249 \\
B10 & 0.953 & 0.106 & -0.215 \\
B11 & -0.286 & 0.194 & 0.873 \\
\hline
\end{tabular}

As can be seen from Table 8 , the three indicators included in the funding input contribute the most to the college's ability to allocate entrepreneurial resources, followed by teacher input. The score coefficient matrix for the three factors is shown in Table 9.

Table 9

Component Score Coefficient Matrix of Entrepreneurial Resource Allocation Ability Evaluation

\begin{tabular}{lccc}
\hline Index & $\mathrm{F}_{1}$ & $\mathrm{~F}_{2}$ & $\mathrm{~F}_{3}$ \\
\hline B6 & -0.368 & 0.279 & -0.546 \\
B7 & 0.071 & 0.457 & 0.226 \\
B8 & 0.052 & 0.481 & -0.041 \\
B9 & 0.405 & 0.072 & -0.087 \\
B10 & 0.412 & 0.059 & -0.039 \\
B11 & 0.015 & 0.063 & 0.792 \\
\hline
\end{tabular}

According to Table 9, it can be concluded that the linear combination between each evaluation indicator is:

$$
\begin{aligned}
& F_{1}=-0.368 \mathrm{~B}_{6}+0.071 \mathrm{~B}_{7}+0.052 \mathrm{~B}_{8}+0.405 \mathrm{~B}_{9}+0.412 \mathrm{~B}_{10}+0.015 \mathrm{~B}_{11} \\
& F_{2}=0.279 \mathrm{~B}_{6}+0.457 \mathrm{~B}_{7}+0.481 \mathrm{~B}_{8}+0.072 \mathrm{~B}_{9}+0.059 \mathrm{~B}_{10}+0.063 \mathrm{~B}_{11} \\
& F_{3}=-0.546 \mathrm{~B}_{6}+0.226 \mathrm{~B}_{7}-0.041 \mathrm{~B}_{8}-0.087 \mathrm{~B}_{9}-0.039 \mathrm{~B}_{10}+0.792 \mathrm{~B}_{11}
\end{aligned}
$$

According to the factor score coefficient matrix, a comprehensive scoring model can be established:

$$
\mathrm{F}=\sum_{i=1}^{m} \alpha_{i} F_{i}=0.41286 \times F_{1}+0.32745 \times F_{2}+0.15548 \times F_{3}
$$




\section{Entrepreneurial process action ability evaluation.}

Table 10

Test Results of KMO and Bartlett for Entrepreneurial Process Action Ability Evaluation

\begin{tabular}{llc}
\hline KMO Value & & 0.629 \\
\hline & Approximate chi square & 21.962 \\
Bartlett sphericity test & Freedom & 10 \\
& Saliency & 0.017 \\
\hline
\end{tabular}

As shown in Table 10, the KMO statistic of each indicator of the entrepreneurial process action ability is 0.629 , and the $\mathrm{P}$ value is 0.017 . It is suitable for factor analysis. The specific feature value and variance contribution rate result of each indicator are shown in Table 11.

Table 11

Eigenvalue and Variance Contribution Rate of Entrepreneurial Process Action Ability Evaluation Indicators

\begin{tabular}{cccc}
\hline Principal component & Characteristic value & Contribution rate & Cumulative contribution value \\
\hline 1 & 2.896 & $60.318 \%$ & $60.318 \%$ \\
2 & 1.296 & $20.693 \%$ & $81.011 \%$ \\
3 & 1.014 & $11.926 \%$ & $92.937 \%$ \\
4 & 0.325 & $5.728 \%$ & $98.665 \%$ \\
5 & 0.168 & $1.335 \%$ & $100.000 \%$ \\
\hline
\end{tabular}

From Table 11, we can see that the cumulative contribution rate of the first three factors is $92.937 \%$, which is higher than $85 \%$. This shows that the first three factors can fully explain the indicator of the entrepreneurial process action ability. See Table 12 for the rotation load matrix.

Table 12

Rotation Load Matrix of Entrepreneurial Process Action Ability Evaluation Indicators

\begin{tabular}{lccc}
\hline \multirow{2}{*}{ Index } & Factor & \multicolumn{2}{c}{} \\
\cline { 2 - 4 } & $\mathrm{F}_{1}$ & $\mathrm{~F}_{2}$ & $\mathrm{~F}_{3}$ \\
\hline B12 & -0.318 & 0.887 & -0.216 \\
B13 & -0.194 & 0.921 & 0.063 \\
B14 & 0.926 & -0.318 & 0.061 \\
B15 & 0.948 & -0.228 & 0.267 \\
B16 & 0.315 & -0.058 & 0.947 \\
\hline
\end{tabular}

From Table 12, it can be seen that the two indicators included in the entrepreneurial project have the highest contribution to the college's entrepreneurial process action ability, followed by the entrepreneurial curriculum. The score coefficient matrix of the three factors is shown in Table 13.

Table 13

Component Score Coefficient Matrix of Entrepreneurial Process Action Ability Evaluation

\begin{tabular}{lccc}
\hline Index & $\mathrm{F}_{1}$ & $\mathrm{~F}_{2}$ & $\mathrm{~F}_{3}$ \\
\hline B12 & 0.227 & 0.583 & -0.192 \\
B13 & 0.131 & 0.646 & 0.153 \\
B14 & 0.628 & 0.114 & -0.189 \\
B15 & 0.679 & 0.158 & -0.225 \\
B16 & -0.314 & 0.016 & 1.137 \\
\hline
\end{tabular}

According to Table 13, it can be concluded that the linear combination between each evaluation indicator is:

$$
F_{1}=0.227 \mathrm{~B}_{12}+0.131 \mathrm{~B}_{13}+0.628 \mathrm{~B}_{14}+0.679 \mathrm{~B}_{15}-0.314 \mathrm{~B}_{16}
$$




$$
\begin{aligned}
& F_{2}=0.583 \mathrm{~B}_{12}+0.646 \mathrm{~B}_{13}+0.114 \mathrm{~B}_{14}+0.158 \mathrm{~B}_{15}+0.016 \mathrm{~B}_{16} \\
& F_{3}=-0.192 \mathrm{~B}_{12}+0.153 \mathrm{~B}_{13}-0.189 \mathrm{~B}_{14}-0.225 \mathrm{~B}_{15}+1.137 \mathrm{~B}_{16}
\end{aligned}
$$

According to the factor score coefficient matrix, a comprehensive scoring model can be established:

$$
\mathrm{F}=\sum_{i=1}^{m} \alpha_{i} F_{i}=0.58752 \times F_{1}+0.24296 \times F_{2}+0.10763 \times F_{3}
$$

\section{Entrepreneurial result performance evaluation.}

Table 14

Test results of KMO and Bartlett for Entrepreneurial Result Performance Ability Evaluation

\begin{tabular}{lll}
\hline KMO Value & 0.538 & 24.092 \\
& Approximate chi square & 16 \\
Bartlett sphericity test & Freedom & 0.025 \\
\hline
\end{tabular}

As shown in Table 14, the KMO statistic for each indicator of entrepreneurial result performance ability is 0.538 , and the $\mathrm{P}$ value is 0.025 . It is suitable for factor analysis. See Table 15 for details of the eigenvalues and variance contribution rates of each indicator.

Table 15

Eigenvalue and Variance Contribution Rate of Entrepreneurial Result Performance Ability Evaluation Indicator

\begin{tabular}{cccc}
\hline Principal component & Characteristic value & Contribution rate & Cumulative contribution value \\
\hline 1 & 3.528 & $51.257 \%$ & $51.257 \%$ \\
2 & 1.629 & $19.319 \%$ & $70.576 \%$ \\
3 & 1.015 & $17.027 \%$ & $87.603 \%$ \\
4 & 0.625 & $9.296 \%$ & $96.899 \%$ \\
5 & 0.528 & $2.274 \%$ & $99.173 \%$ \\
6 & 0.091 & $0.827 \%$ & $100.000 \%$ \\
\hline
\end{tabular}

From Table 15, we can see that the cumulative contribution rate of the first three factors is $88.048 \%$, which is higher than $85 \%$. This shows that the first three factors can fully explain the indicator of entrepreneurial result performance ability. See Table 16 for the rotation load matrix.

Table 16

Rotation Load Matrix of Entrepreneurial Result Performance Ability Evaluation Indicators

\begin{tabular}{lccc}
\hline Index & \multicolumn{3}{c}{ Factor } \\
& $\mathrm{F}_{1}$ & $\mathrm{~F}_{2}$ & $\mathrm{~F}_{3}$ \\
\hline B17 & 0.147 & 0.921 & 0.282 \\
B18 & 0.139 & 0.895 & 0.168 \\
B19 & 0.962 & 0.269 & 0.082 \\
B20 & 0.116 & 0.378 & 0.883 \\
B21 & 0.498 & 0.264 & 0.821 \\
B22 & 0.892 & 0.047 & 0.491 \\
\hline
\end{tabular}

Table 17

Component Score Coefficient Matrix of Entrepreneurial Result Performance Ability Evaluation

\begin{tabular}{lccc}
\hline Index & $\mathrm{F}_{1}$ & $\mathrm{~F}_{2}$ & $\mathrm{~F}_{3}$ \\
\hline B17 & -0.069 & 0.593 & -0.096 \\
B18 & -0.038 & 0.647 & -0.225 \\
B19 & 0.651 & 0.112 & -0.412 \\
B20 & -0.302 & -0.048 & 0.763 \\
B21 & 0.053 & -0.195 & 0.528 \\
B22 & 0.471 & -0.199 & 0.084 \\
\hline
\end{tabular}


From Table 16, we can see that the two indicators included in social benefits have the highest contribution to the entrepreneurial result performance ability of colleges and universities, followed by the promotion of literacy. See Table 17 for details of the score coefficient matrix for the three factors.

According to Table 17, it can be concluded that the linear combination between each evaluation indicator is:

$$
\begin{aligned}
& F_{1}=-0.069 \mathrm{~B}_{17}-0.038 \mathrm{~B}_{18}+0.651 \mathrm{~B}_{19}-0.302 \mathrm{~B}_{20}+0.053 \mathrm{~B}_{21}+0.471 \mathrm{~B}_{22} \\
& F_{2}=0.593 \mathrm{~B}_{17}+0.647 \mathrm{~B}_{18}+0.112 \mathrm{~B}_{19}-0.048 \mathrm{~B}_{20}-0.195 \mathrm{~B}_{21}-0.199 \mathrm{~B}_{22} \\
& F_{3}=-0.096 \mathrm{~B}_{17}-0.225 \mathrm{~B}_{18}-0.412 \mathrm{~B}_{19}+0.763 \mathrm{~B}_{20}+0.528 \mathrm{~B}_{21}+0.084 \mathrm{~B}_{22}
\end{aligned}
$$

According to the factor score coefficient matrix, a comprehensive scoring model can be established:

$$
\mathrm{F}=\sum_{i=1}^{m} \alpha_{i} F_{i}=0.56382 \times F_{1}+0.19274 \times F_{2}+0.11092 \times F_{3}
$$

Comprehensive evaluation. Based on the above analysis and combined with the actual data of the four universities of Renmin University of China, Tsinghua University, Wuhan University, and Heilongjiang University, the weights of the four major indicators can be calculated. See Table 18 for details.

Table 18

The Indicator Weight of The Evaluation of the Level of Entrepreneurship Education in 4 Colleges and Universities

\begin{tabular}{lcccc}
\hline $\begin{array}{l}\text { The evaluation result } \\
\text { of the level of } \\
\text { entrepreneurship } \\
\text { education }\end{array}$ & $\begin{array}{l}\text { Entrepreneurial } \\
\text { environment } \\
\text { basic ability }\end{array}$ & $\begin{array}{l}\text { Entrepreneurial } \\
\text { resource } \\
\text { allocation ability }\end{array}$ & $\begin{array}{l}\text { Entrepreneurial } \\
\text { process ability }\end{array}$ & $\begin{array}{l}\text { Performance } \\
\text { capability of } \\
\text { entrepreneurial } \\
\text { achievement }\end{array}$ \\
\hline Indicator weight & 0.2736 & 0.2248 & 0.2169 & 0.2847 \\
\hline
\end{tabular}

The formula for comprehensive evaluation is:

$$
Z_{j}=\omega_{1} Y_{1 j}+\omega_{2} Y_{2 j}+\cdots+\omega_{m} Y_{m j}=\sum_{i=1}^{m} \omega_{i} Y_{i j} \quad \mathrm{j}=1,2, \ldots, \mathrm{n}
$$

According to formula (13), the comprehensive evaluation results of entrepreneurship education levels in four universities can be obtained. See Table 19 for details.

Table 19

The Results Of Comprehensive Evaluation of The Level of Entrepreneurship Education in 4 Colleges and Universities

\begin{tabular}{lcccc}
\hline \multicolumn{1}{c}{} & $\begin{array}{c}\text { Renmin } \\
\text { University of } \\
\text { China }\end{array}$ & $\begin{array}{c}\text { Tsinghua } \\
\text { University }\end{array}$ & $\begin{array}{c}\text { Wuhan } \\
\text { University }\end{array}$ & $\begin{array}{c}\text { Heilongjiang } \\
\text { University }\end{array}$ \\
\hline $\begin{array}{l}\text { The results of comprehensive } \\
\text { evaluation on the level of } \\
\text { entrepreneurship education }\end{array}$ & 68.79 & 92.93 & 82.16 & 71.23 \\
\hline
\end{tabular}

\section{Conclusion}

4.1 The start-up of entrepreneurship education in Chinese universities is relatively late compared to foreign countries. At present, many domestic universities and colleges have carried out entrepreneurship education 
through various means. The degree of student participation is relatively high, but the overall satisfaction of students is not high. This shows that colleges and universities still need to make great efforts to promote the sustainable development of entrepreneurship education in colleges and universities.

4.2 Based on the research results of domestic and foreign experts, and according to the relevant theories of the CIPP model, this paper establishes an evaluation indicator system of college entrepreneurship education level based on the CIPP model, which mainly includes the four basic principles of environmental basis, resource allocation, process actions, and results performance, all 4 primary indicators.

4.3 Through factor analysis, the weights of indicators in the evaluation indicator system of college entrepreneurship education levels can be calculated, and the entrepreneurial education level of Renmin University of China, Tsinghua University, Wuhan University, and Heilongjiang University can be calculated based on the actual data of the four universities. The overall evaluation results were $69.79,92.93,82.16$, and 71.23 , respectively.

\section{References}

Apley, D. W., \& Shi, J. (2001). A factor-analysis method for diagnosing variability in mulitvariate manufacturing processes. Technometrics, 43(1), 84-95. http://dx.doi. org/10.1198/00401700152404354

Behzad, S., Parasto, G., \& Arash, N. (2013). The evaluation of mothers' participation project in children's growth and development process: using the CIPP evaluation model. Journal of Education \& Health Promotion, 2(1), 1405-1410. http://dx.doi. org/10.4103/2277-9531.112692

Birnbaum, K., Benfey, P. N., \& Shasha, D. E. (2001). Cis element/transcription factor analysis (cis/tf): a method for discovering transcription factor/cis element relationships. Genome Research, 11(9), 1567. http://dx.doi. org/10.1101/gr.158301

Fan, J. Y., Wang, Y. H., Chao, L. F., Jane, S. W., \& Hsu, L. L. (2015). Performance evaluation of nursing students following competency-based education. Nurse Education Today, 35(1), 97-103. http://dx.doi. org/10.1016/j.nedt.2014.07.002

Hopke, P. K. (1988). Target transformation factor analysis as an aerosol mass apportionment method: a review and sensitivity study. Atmospheric Environment, 22(9), 1777-1792. http://dx.doi. org/10.1016/00046981(88)90066-2

Jablonsky, J. (2016). Efficiency analysis in multi-period systems: an application to performance evaluation in czech higher education. Central European Journal of Operations Research, 24(2), 283-296. http://dx.doi. org/10.1007/s10100-015-0401-Z

Liu, L., Chen, D. Q., Bose, I., Hu, N., \& Bruton, G. D. (2013). Core versus peripheral information technology employees and their impact on firm performance. Decision Support Systems, 55(1), 186-193. http://dx.doi. org/10.1016/j.dss.2013.01.018

Lorber, A. (1985). Features of quantifying chemical composition from two-dimensional data array by the rank annihilation factor analysis method. Analytical Chemistry, 57(12), 2395-2397. http://dx.doi. org/10.1021/ac00289a052 
Miyazaki, N., Ikeda, T., Soda, T., \& Munakata, T. (1993). Stress intensity factor analysis of interface crack using boundary element method-application of contour-integral method. Engineering Fracture Mechanics, 45(5), 599-610. http://dx.doi. org/10.1016/0013-7944(93)90266-u

Mosqueda, M. R. P., Tollner, E. W., Boyhan, G. E., Li, C. Y., \& Mcclendon, R. W. (2009). Simulating onion packinghouse product flow for performance evaluation and education. Biosystems Engineering, 102(2), 135-142. http://dx.doi. org/10.1016/j.biosystemseng.2008.09.021

Neyazi, N., Arab, P. M., Farzianpour, F., \& Mahmoudi, M. M. (2016). Evaluation of selected faculties at tehran university of medical sciences using cipp model in students and graduates' point of view. Evaluation \& Program Planning, 59, 88-93. http://dx.doi. org/10.1016/j.evalprogplan.2016.06.013

Prathap, G., \& Ratnavelu, K. (2015). Research performance evaluation of leading higher education institutions in malaysia. Current Science, 109(6). http://dx.doi. org/10.18520/cs/v109/i6/1159-1164

Prescott, L. E., Norcini, J. J., Mckinlay, P., \& Rennie, J. S. (2002). Facing the challenges of competency-based assessment of postgraduate dental training: longitudinal evaluation of performance (lep). Medical Education, 36(6), 92-97. http://dx.doi. org/10.1046/j.1365-2923.2002. 01099.x

Singh, M. D. (2004). Evaluation framework for nursing education programs: application of the CIPP model. International Journal of Nursing Education Scholarship, 1(1), Article13. http://dx.doi. org/10.2202/1548$923 \times .1023$

Stommel, M., Wang, S., Given, C. W., and Given, B. (1992). Focus on psychometrics confirmatory factor analysis (cfa) as a method to assess measurement equivalence. Research in Nursing and Health, 15(5), 399. http://dx.doi. org/10.1002/nur.4770150508

Trevisan, M. G., Garcia, C. M., Schuchardt, U., \& Poppi, R. J. (2008). Evolving factor analysis-based method for correcting monitoring delay in different batch runs for use with PLS: On-line monitoring of a transesterification reaction by ATR-FTIR. Talanta,74(4), 971-976. http://dx.doi. org/10.1016/j.talanta.2007.08.004 